\title{
Challenges and Barriers in Convergence of IND_AS with IFRS: A Perspective Investigation on Indian Professionals and Officials
}

\author{
Lohrasp Sadri ${ }^{1}$ \\ ${ }^{1}$ Curtin University Dubai, UAE \\ Correspondence: Lohrasp Sadri, Curtin University Dubai, UAE
}

Received: August 20, 2019

Accepted: September 5, 2019

Online Published: September 9, 2019

doi:10.5430/afr.v8n4p25

URL: https://doi.org/10.5430/afr.v8n4p25

\begin{abstract}
Purpose: The paper examines the perception of officials and professionals in implementing IFRS at pre-initial stage. India accepted to implement the IFRS from $1^{\text {st }}$ April 2016 despite reluctance from practitioners. Paper explores the responses towards challenges in implementation of IFRS rather than its effects after implementation.

Design / Methodology / Approach: Quantitative research is used with use of structured questionnaire. The survey provided 192 responses from across India.

Findings: Study questioned the readiness in adoption of IFRS and handling the challenges. Both officials and professionals have similar concern in implementing IFRS. Both groups agreed on the importance and usefulness of globally harmonizing AS but do not find it easy to adapt IND-AS to IFRS and have many concerns over it. Moreover, IASB is not properly emphasising in smoothening the process of implementation other than just organizing training sessions. Young and skilled professionals appreciated more of IFRS implementation than elderly and less skilled. Female participants are more receptive than men. Indian software companies were already using US GAAP norms for more than a century.
\end{abstract}

Implications / Contributions: Analysis suggested IASB to focus on implementing issues and must work in coordination with national boards of every country to address those issues locally.

Suggestions: Involvement of corporate houses, local authorities, boards, national agencies, professionals and officials are required for success of IFRS adoption. The Author is preparing to submit a report to IASB to facilitate them in bringing effectiveness for the same purpose.

Originality of Study / Importance: The study focuses on issues specifically raised by officials and professionals of India. No study conducted with this perspective especially on India.

Scope of Study: Based on the literature review, corporate governance is identified as an important area as the scope of this study in order to bring the effectiveness of implementation phase of IFRS within Indian companies, and to identify different factors that increases risk of failure. Further, it is important to study the role of monitoring institutions, regulators, and government in encouraging professionals and officials to smoothen the implementation phase in India. Nevertheless, effects after implementation need to be studied further.

Keywords: IFRS, IASB, convergence, challenges, adoption

Abbreviations: "International Financial Reporting Standards (IFRS), Ministry of Corporate Affairs (MCA), International Accounting Standards Committee (IASC), National Accounting Standards Advisory Committee (NASAC), India Institute of Chartered Accountants (ICAI), Neo Institutional Theory (NIT), Indian Generally Accepted Accounting Standards (Ind GAAP), Indian Accounting Standards (Ind-AS), Non-Performing Loans (NPL), Non-Corporate Entity (NCE), Corporate Entity (CE), Banking-Finance-Insurance (BFI), Business Processing Organizations (BPO), Accounting Standards (AS), Accounting Professionals to be read as 'Professionals', Banking Officials to be read as 'Officials'.'

\section{Introduction}

It has been around 18 years since the IASB started effectively applying its IFRS in 2001. A recent extensive IASB research shows that most countries are committed to moving towards IFRS. However, due to intuitive stress, many of these countries react to IFRS implementation (Phan, D., Joshi, M., \& Mascitelli, B., 2016) (Sharma, S., Joshi, M., \& Yapa, P., 2016) (Mir, Monir, \& Shiraz Rahaman, Abu., 2005). Research involvement in IFRS has shifted from 
acceptance to execution problems. Such problems also attracted concerns from stakeholders such as the preparation of reports, professionals, officials, bodies, consumers, and researchers.

Research concentrate on IFRS issues has shifted from IFRS issuance procedures worldwide and IFRS distributed to knowing the perspectives and difficulties of IFRS application (Ahmed, Kamran \& Ali, Muhammad.,2015) (Barth, M. E., Landsman, W. R., Lang, M., and Williams, C.,2012) (Brüggemann, U., Hitz, J.-M., and Sellhorn, T., 2013) (Joshi, M., Yapa, P., and Kraal, D., 2016) (Rezaee, Zabihollah, Smith, Murphy, and Z., Szendi, Joseph., 2010) (Yip, Rita, and Young, Danqing, 2012). The result of such attempts may also affect the choice of jurisdictions and transitional measures yet to be adopted.

The main goals of the IASB are described in its 'IFRS Preface' (IFRS., 2018) that can be divided in two parts: First, setting superior quality and comprehensible AS; and second, making it appropriate and applicable, globally.

Under present state of execution of IFRS at global level, with many countries committing to the application of IFRS, need is to give due consideration on other elements of IASB objectives as recent requests have seen similar problems with those faced ten years previously by early adopters (Jermakowicz, Eva, \& Gornik-Tomaszewski, Sylwia., 2006) (Jones, Stewart, and D., Higgins, Alison., 2006) (Weaver, Lisa, and Woods, Margaret., 2015) (I. Ocheni, S., 2015).

In many countries, the job of enforcing IFRS is further complex by constantly changing IFRS, and not yet finalized. This task diminishes the chance of a soft shift to complete accordance (Joshi, PL, Bremser, WG, and Al-Ajmi, J., 2008). Also, the apparent barriers and difficulties of stakeholder application of IFRS have developed barriers to IFRS convergence with national AS.

Similar views are conveyed by writers when they observe that although distinct aspects have been discussed in the literature on the topic of worldwide accounting harmonisation, execution issues such as execution costs, consciousness, instruction and data technologies also need consideration.

The last century has seen sporadic attempts to recognize the difficulties of implementing IFRS in terms of interaction, translation and analysis of IASB norms and to comprehend the difficulties experienced by officials and professionals in terms of education, staffing, costs, preparation and IT facilities (Jermakowicz, Eva, \& Gornik-Tomaszewski, Sylwia., 2006) (Jones, Stewart, and D., Higgins, Alison., 2006) (Weaver, Lisa, and Woods, Margaret., 2015) (I. Ocheni, S., 2015).

Because of organizational stress, emerging countries with a relatively less advanced accounting and supervisory structure have embraced IFRS (Ball, Ray., 2006) (Jones, Stewart, and Finley, Aimee., 2011). Many of these countries were initially reluctant to embrace because of execution problems (ICAI., 2014). Such problems have been gradually resolved or postponed with the implementation of one phase. (Phan, D., Joshi, M., \& Mascitelli, B., 2016) (Sharma, S., Joshi, M., \& Yapa, P., 2016).

India has taken a step-by-step convergence method with IFRS. The current study will assist to know whether in a method of gradual implementation, the transitional problems encountered during the one-step implementation of IFRS are prevented. To explore the amount of readiness to embrace IFRS and the difficulties experienced in implementing the IFRS, a thorough research is required to be conducted to know the opinions of both officials and professionals in preliminary stage itself.

In 2016-17, India become the part of IFRS development process when, in 2016-17, the MCA announced its framework to introduce Indian Accounting Standards (Ind-AS). This study is encouraged to discover the problems and difficulties experienced in the implementation of IFRS-based AS by authorities, professionals, and officials in India. This prompt research seeks to investigate participants' views of their consciousness and readiness for the problems of alignment with Ind-AS during the pre-adoption stage. The study will explore the previous research issues for this purpose as:

Research Issue 1: What is the ICAI readiness to converge with IFRS evaluation of practitioners and experts?

Research Issue 2: What are the significant difficulties of implementing the suggested IFRS convergence in India?

Research Issue 3: Whether professionals and officials have comparable views points on issues related to IFRS execution readiness and difficulties or not. Whether demographic parameters such as gender, knowledge, qualification and possession of job influences viewpoints or not.

Research available gauges stakeholder attitudes towards financial report consumers (Morris, Richard, Gray, Sidney, Pickering, Joanne, and Aisbitt, Sally., 2014) (Jones, Stewart, and D., Higgins, Alison, 2006) (Jermakowicz, Eva, \& Gornik-Tomaszewski, Sylwia., 2006) (Pawsey, N. L., 2008). This research discusses practitioners' views as document preparers and officials as main consumers of these documents. The banking industry is Indian economy's 
most significant sector and during IFRS integration, it will encounter significant banking-specific and generic difficulties. As a customer, for instance, it emplace its money from clients, savings, and monetary instruments relying on accounting records created as per the standards.

Preparer is accountable for NPL's, hedge accounting testing and measurement, conformity with regulations, and tax related activities (Firoz, C. M., Ansari, A. A., and Akhtar, K., 2011) (Ray, S., 2012). Banking system of India also addresses many accounting and company specific problems and believes that the banking sector will be the most appropriate sector on which the consumers of financial information can share their views on IFRS convergence in accounting practices of India.

The research makes significant contributions to knowledge. Firstly, this research shows execution difficulties such as training, price, and consciousness and many other related issues have not been given adequate consideration while addressing them especially under preview that developing economies have decided to be the part in IASB's worldwide IFRS implementation. Secondly, the research seeks to know the magnitude to which professionals and officials are aware of such problems. Third, the research results will assist boards and authorities toward IFRS convergence or implementation in order to minimize transitional problems. This is also important for the IASB as it aims to successfully and seamlessly implement IFRS globally. Finally, by incorporating views from an emerging economy, this research will create an important addition to the worldwide IFRS literature.

\section{The Current State of IFRS Implementation Process at Global Level}

With the formation of IASC in London in 1973, the significant efforts were made to harmonize AS over the past five decades. This private sector project was established and financed in accordance with a multi-country accounting body's agreement. Within a period of 1973 and 2000, IASC created an extensive roster of AS inclusive of conceptual framework, guidelines and interpretations (Pacter, P., 2014).

In 2001, IASB substituted IASC with bigger financial hand in position to formulate and enforce international AS, supervised by the fresh IFRS Foundation; by 2001 all 41 norms published by the IASC were accepted (Pacter, P., 2014). These norms have been modified and revised in line with business and accounting requirements. In January 2005, IFRS was concurrently implemented by 25 countries of the European Union (EU). This gave European countries a ready-made collection of high-quality AS that substituted the current 25 competing national accounting norms in general (Martin, Hoogendoorn., 2006) (Jeanjean, Thomas, and Stolowy, Hervé., 2008) (Mackintosh, I., 2014).

With the announcement of Australia, South Africa, Hong Kong, and New Zealand implementation of IFRS, gave momentum to the IASB's project to adopt IFRS, globally (Pacter, P., 2014). Unlike these states' one-step implementation of IFRS, there are also countries that have chosen to gradually integrate IFRS. India is one such instance and has launched a gradual method of compliance with international AS (Ahmed, Kamran, and Ali, Muhammad., 2015).

IASB argues that 130 nations have a public dedication to its worldwide execution in having one standard of accounts. Of these 116 nations, all or most of their responsible institutions carry IFRS; whereas the remaining nations allowed IFRS for those organizations listed on stock exchanges. It was noted that India decided to embrace IFRS due to coercive stress from outside world dependence on resources and technological resources (Sharma, S., Joshi, M., and Yapa, P., 2016).

NIT has been used as a national accounting norm in numerous research (E. Barbu, and C. Richard Baker., 2009) (Guerreiro, Marta Silva, Rodrigues, Lúcia Lima, and Craig, Russell., 2012) (Mahzan, Nurmazilah, 2013) (Mir, Monir, and Shiraz Rahaman, Abu, 2005) to examine the increase and extensive acceptance of IFRS. NIT describes how IFRS framework come into existence and behave as a reference point or prescription for different members or stakeholders for social behaviour. It investigates how agreements or contracts, norms or standards, and routine unite, cease, or decline. It analyses the shift to agreement \& conformity, disputes and hurdles the stakeholders experienced prior to achieve sustainability. Research aimed to examine the grounds for the implementation of IFRS by emerging economies with recognized assets and resources dependencies as the reasons for the implementation of IFRS ) (Mahzan, Nurmazilah, 2013) (Mir, Monir, and Shiraz Rahaman, Abu, 2005).

Considering that these nations are characterized by a variety of country-specific characteristics, the implementation of IFRS by such numbers of nations is a wonderful accomplishment (Ball, Ray., 2006) (Bhattacharyya, K., 2012). The social, legal, economical, technological and political structure affect their choice to opt either for one-step acceptance or for gradual IFRS convergence (Dhankar, R. S., and Gupta, A., 2014) (Upton, Wayne., 2010) . Many of 
these countries for different purposes substituted their in-practice AS with IFRS, although some of them were reluctant at first.

India pursued a strategy of gradual convergence to IFRS and addresses several local problems to minimize the effect of convergence, till the time, IFRS reporting is reflected within financial reporting as per Indian AS.

The cause for IFRS implementation in India was resource dependence and ongoing communication with the outside world. Currently, Ind GAAP is matched with U.S. GAAP, and the main distinction lies in the approach towards IFRS as later (IFRS) is based on principles; whereas, former (US GAAP) is based on rules (Braun, G. P., Haynes, C. M., Lewis, T. D., and Taylor, M. H., 2015). Other particular problems (such as technical issues, and multi-layered legal institutional - regulatory frameworks) and generic problems need to be addressed.

The alternatives to these problems involve prompt cooperation for accounting and auditing between different elements of the Indian parliamentary and regulatory structure (Firoz, C. M., Ansari, A. A., and Akhtar, K., 2011). In 2007, ICAI started the process of creating full-fledged IFRS-converging Ind-AS. While formulating the standards in convergence to IFRS, due consideration was given on circumstances and practices followed within India to incorporate them as far as feasible.

The MCA of India is responsible for convergence of Ind-AS with that to IFRS, and announced the strategic framework to enforce Ind-AS from $1^{\text {st }}$ April 2011. However, this deadline was postponed in perspective of ongoing settlement of several tax problems, the accounting legislative structure, consciousness, coaching and price of execution (Dhankar, R. S., and Gupta, A., 2014) (Firoz, C. M., Ansari, A. A., and Akhtar, K., 2011).

Finally, MCA re-announced the implementation of the Ind-AS from 2016-17 via press release of $6^{\text {th }}$ January 2015 followed by a roadmap designed to implement Ind-AS, announced via press release on $18^{\text {th }}$ January 2016 . The Ind-AS roadmap has a systematic strategy centred on a company's net worth and other considerations such as trade cards within and outside India.

\section{Literature Review}

The design and execution of IASB-initiated worldwide AS has been widely supported by countless national or international accounting authorities and organizations. The Literature on IFRS available globally spotlighted the reasons, effects of experience, practical diversity, and the challenges of IFRS implementation. As stated above, the variables that render execution uncertain are also identified by researchers (Weaver, Lisa, and Woods, Margaret., 2015) when they noted that while a variety of aspects on worldwide accounting harmonization are discussed in the current literature, application problems such as execution costs, consciousness, preparation and IT are also need to be addressed.

It was noted that beneficiaries face difficulties during execution - employee learning, process realignment as well for the future with respect to curriculum modifications to match the abilities of graduates with modifications in accounting procedures (I. Ocheni, S., 2015). Challenges were noted regarding the absence of instruction in implementation stage of IFRS for Belgian listed companies revealing the danger of multiple mistakes during the disclosure of IFRS (Eva, K. Jermakowicz., 2004).

Mixed findings on the advantages faced with IFRS adoption are presented in the accessible literature, but there is agreement on the problems encountered during execution (Ball, Ray., 2006) (Jones, Stewart, and D., Higgins, Alison., 2006). In studying professionals and officials' perceptions representing Australia's top 200 organizations, it reported the concerns about the advantages of implementing IFRS, but participants voiced common opinions on the price of implementing it (Jones, Stewart, and D., Higgins, Alison., 2006).

Researchers recognized practical execution difficulties in practice and other technicalities encountered by managers, preparers, and inform consumers (A., Zeff, Stephen., 2007). Researcher performed a survey-based study in 2005 directed at knowing EU trading firms' tentative attempts towards IFRS implementation (Jermakowicz, Eva, \& Gornik-Tomaszewski, Sylwia., 2006). This was the first set of nations to embrace IFRS, so they had no previous execution knowledge on which to build. Jurisdictions that chose for IFRS single-step adoption revealed the method of implementing IFRS as expensive, complicated and burdensome for EU-listed businesses (Jermakowicz, Eva, \& Gornik-Tomaszewski, Sylwia., 2006).

In another questionnaire-based research, it is noted that the financial managers of registered Romanian businesses were concerned with coaching, changes to information technologies and execution consultancy-related expenses (Ion Ionas $_{s} \mathrm{cu}$, Mihaela Ionas,cu, Lavinia Olimid, and Daniela Artemisa Calu., 2007). Similarly, professionals and officials' attitudes with IFRS application knowledge were recorded, recognizing difficulties such as practice and data 
capture that hold priority over particular IFRS consequences. Training of potential accountants was seen as a significant problem during and after IFRS application (Heidhues, E., and Patel, C., 2008).

In India, the postponement of the application of the Ind-AS on $1^{\text {st }}$ April 2011, the NASAC quoted factors such as the ongoing settlement of several tax and environmental problems and the difficulties of application in terms of knowledge, preparation and execution costs (Dhankar, R. S., and Gupta, A., 2014).

The NASAC is the Central Government's regulatory consultative committee on formulating and implementing company compliance accounting policies and norms. India's focus to align it's AS in convergence to IFRS gains momentum in the year 1991 when bureaucrats liberalized the economy to attract international involvement in innovation, business and capital investments (E. Perumpral, Shalini, Evans, Mark, Agarwal, Sanjay, and Amenkhienan, Felix., 2009).

Considering US being the main source of these resources; India matched its AS with that to US GAAP to intersect with translucency in reporting process (Riahi-Belkaoui, A., 1994). Successful coordination of Ind GAAP with US GAAP prompted vital international involvement in Indian companies, in addition to offering ICAI with expertise and credibility in putting about such improvements in AS, governance, coaching and legislative frameworks.

It was the day of Friday i.e. $1^{\text {st }}$ April 2016 when MCA's announced the roadmap for Ind-AS implementation, that not only strengthened the commitment of Government of India to adopt Ind-AS, but also sparked the rounds of discussions on implementation challenges for stakeholders. During the execution phase in India, issues such as knowledge, preparation, cost, data collection and interpretation, IT facilities and staffing were generally viewed as problems for banking and other sectors with some demographic variations (Adhana, D. K., 2015) (Dhankar, Raj, Chaklader, Barnali, and Gupta, Amit., 2015) (Mishra, S. K., and Aggarwal, V., 2014). In the framework of other countries, such comments on problems during the Ind-AS execution methods were gleaned from the accessible literature.

\section{Research Methodology}

The literature shows that from explanatory and quantitative studies on IFRS and other topics, a questionnaire study method is best suited to investigate respondents' views of multiple elements of transition in organizational environment. In this research, the same methodology was used. It is also appropriate in big geographical regions for acquiring large sample dimensions.

Construction of questionnaire is such to address two aspects of study. First, to collect information on demographics of participants. Second, to include the statements that will answer the research questions. Two sequences of observations were used in questionnaire to gauge the sensitivity and readiness of participants for convergence to IFRS. The first eight remarks apply to the first research question and are therefore designed and were put on Likert Scale (5 point rating scale) to determine respondents' consciousness on difficulties in way to IFRS convergence and to access their opinion on ICAI readiness on effective implementation of the process.

The second research question related to significant execution problems in the suggested IFRS convergence in India was discussed by another six statements, which were put on same Likert-scale (5 point rating scale) format in reverse order as: 5: Strongly Disagree (SD), 4: Disagree (D) represents agreement w.r.t. statements; whereas, 1: Strongly Agree (SA), 2: Agreement (A) shows disagreement w.r.t. statements; 3: Neutral (N) opinion.

Professionals \& officials were encouraged to introduce their opinions on IFRS execution sensitivity and readiness to handle difficulties. Professionals have been contacted as they are the main stakeholders in the application method of IFRS and are strongly influenced by activities of accounting bodies. The literature accessible examines the attitudes of users only, ignoring the preparers of these financial statements (Jermakowicz, Eva, \& Gornik-Tomaszewski, Sylwia., 2006) (Jones, Stewart, and D., Higgins, Alison., 2006) (Morris, Richard, Gray, Sidney, Pickering, Joanne, and Aisbitt, Sally., 2014) (Pawsey, N. L., 2008). It was asserted that in the pre-adoption stage, facing both professionals and officials would provide a healthy attitude to the research.

The Chartered Accountants (CA) are ICAI employees in the event of India. This affiliation is given by accounting body after completing the examinations and coaching. Members also engage themselves in numerous coaching programs and obtain frequent updates on recent trends. ICAI initiated a training program besides including the contents on Ind-AS in its study curriculum. Officials constitutes the mix of internal or primary customers (workers, governance, shareholders) and external or secondary customers (creditors and shareholders) (Firoz, C. M., Ansari, A. A., and Akhtar, K., 2011) (Ray, S., 2012). In addition, the banking industry is considered to face substantial, exclusive, and pervasive difficulties during IFRS pre-and-post implementation procedures (RBI, 2011) (Fox A., Hannah, G., Helliar, C., and Veneziani, M., 2013). 
The survey instrument were either self-distributed, or as mailers, or by e-mail to the participants. Official's names and locations have been acquired from respective bank website; whereas, CA list was obtained from ICAI headquarters and respondents details from the ICAI members' directory. For the purpose of this research, stratified random sampling was used. To guarantee a healthy view, the research instruments were sent to a randomly chosen set of professionals and officials from various areas of the nation.

For research purposes, officials operating in main or regional offices have been approached. Appropriate measures have been adopted to guarantee the anonymity and confidentiality of the participants. Between January 2019 and March 2019, the study was performed approaching 500 recognized potential participants (250 practitioners and 250 experts). 219 participants received the questionnaires; 27 were rejected because of incompleteness. Out of available 192 questionnaires, 79 (31.6\%) were officials, and $113(45.2 \%)$ were professionals. Table-1 offers an outline of the respondents ' demographic status.

Table 1. Descriptive Statistics

\begin{tabular}{|c|c|c|}
\hline Respondents & Total $=192$ & Percentage \\
\hline \multicolumn{3}{|l|}{ Nature of Respondents } \\
\hline Officials & 79 & 41.2 \\
\hline Professionals & 113 & 58.8 \\
\hline \multicolumn{3}{|l|}{ Gender } \\
\hline Male & 154 & 80.2 \\
\hline Female & 38 & 19.8 \\
\hline \multicolumn{3}{|l|}{ Age (in Years) } \\
\hline$\leq 30$ & 57 & 29.8 \\
\hline $31-40$ & 44 & 22.9 \\
\hline $41-50$ & 65 & 33.8 \\
\hline$>50$ & 26 & 13.5 \\
\hline \multicolumn{3}{|l|}{ Experience (in Years) } \\
\hline$\leq$ than 15 & 94 & 49 \\
\hline$>$ than 15 & 98 & 51 \\
\hline \multicolumn{3}{|l|}{ Qualifications } \\
\hline Chartered Accountants & 121 & 63 \\
\hline Non-Chartered Accountants & 71 & 37 \\
\hline \multicolumn{3}{|l|}{ Employment Ownership } \\
\hline NCE & 85 & 44.2 \\
\hline $\mathrm{CE}$ & 107 & 55.8 \\
\hline \multicolumn{3}{|l|}{ Affiliation } \\
\hline \multicolumn{3}{|l|}{ Officials (79) } \\
\hline From Top 4 Banks & 13 & 16.5 \\
\hline Other 4 Banks & 66 & 83.5 \\
\hline \multicolumn{3}{|l|}{ Professionals (113) } \\
\hline Top 4 Practitioners & 13 & 6.8 \\
\hline Other 4 Practitioners & 100 & 45.8 \\
\hline \multicolumn{3}{|l|}{ Level in Organisation } \\
\hline Senior Level & 137 & 71.4 \\
\hline Middle Level & 55 & 28.6 \\
\hline
\end{tabular}

\section{Sources: Primary Data}

Descriptive results are comparable to other studies (Innes, John., 1990) (Thorne, Linda, Mahoney, Lois, Manetti and Giacomo., 2014) that answered the first two issues of research. For the third research question, independent sample t-test and Levene's test were used. Similar experiments was carried out to determine variance amongst replies to statements related to gender, experience, and qualifications (Joshi, PL, Bremser, WG, and Al-Ajmi, J., 2008) (Joshi, M., Yapa, P., and Kraal, D., 2016). In order to know whether professionals and officials have comparable views on the issue of consciousness and readiness to handle difficulties in IFRS implementation process, a one-way ANOVA was performed to create inferences about population mean. 


\section{Analysis and Results}

Descriptive results in table-1 have been used to demonstrate participants' population characteristics and to explore their reactions to the questionnaire statements. Independent t-test were carried out to compare means of officials and professionals' responses. Two sample t-test with p-value is used to determine significant difference in sample means.

Table-2 offers the participants perception about ICAI problems and preparations on IFRS convergence. For the assessment of the views of professionals and officials on study problems, table- 3 and table- 4 provide descriptive statistics and t-test result. Table-5 shows the importance of variations in the views of respondents depending on demographic features.

Table 2. Mean of Responses w.r.t. ICAI Readiness towards Challenges of Convergence Process to IFRS

\begin{tabular}{|c|c|c|c|c|}
\hline Statements & Statements Description & Mean & $N$ & $\begin{array}{l}\text { Agreement } \\
\%\end{array}$ \\
\hline A1 & $\begin{array}{l}\text { The financial sector of India is ready for IFRS } \\
\text { integration. }\end{array}$ & 2.7 & 184 & $49 \%$ \\
\hline A2 & $\begin{array}{l}\text { Print and other media provide sufficient information } \\
\text { in our corporate sector after IFRS has been adopted. }\end{array}$ & 3.1 & 184 & $36 \%$ \\
\hline A3 & $\begin{array}{l}\text { We are pleased with ICAI attempts to train } \\
\text { employees. }\end{array}$ & 2.9 & 184 & $42 \%$ \\
\hline A4 & $\begin{array}{l}\text { ICAI newspapers and publications concentrate } \\
\text { sufficiently on IFRS acceptance. }\end{array}$ & 2.6 & 184 & $54 \%$ \\
\hline A5 & $\begin{array}{l}\text { ICAI website provide adequate literature on IFRS } \\
\text { adoption. }\end{array}$ & 2.6 & 185 & $53 \%$ \\
\hline A6 & $\begin{array}{l}\text { ICAI has adopted appropriate steps to promote } \\
\text { transfer w.r.t. roadmap, scheduling, rules and } \\
\text { regulations. }\end{array}$ & 2.8 & 187 & $44 \%$ \\
\hline A7 & $\begin{array}{l}\text { We are pleased with the scope of financial education } \\
\text { in our nation via ICAI, Universities, and Vocational } \\
\text { Institutions etc. }\end{array}$ & 2.5 & 184 & $51 \%$ \\
\hline A8 & $\begin{array}{l}\text { Recent knowledge of upgrading AS to Ind GAAP in } \\
\text { line of US GAAP facilitates India to adopt IFRS. }\end{array}$ & 2.4 & 185 & $57 \%$ \\
\hline
\end{tabular}

Sources: Data Analysis

Table 3. Mean of Responses w.r.t. ICAI Readiness towards Challenges of Convergence Process to IFRS

\begin{tabular}{lllll}
\hline Statements & Nature of Respondents & $\boldsymbol{N}$ & Mean & Std. Deviation \\
\hline A1 & Officials & 75 & 2.6 & .93 \\
& Professionals & 109 & 2.7 & .94 \\
A2 & Officials & 76 & 3.0 & 1.27 \\
& Professionals & 108 & 3.2 & 1.29 \\
A3 & Officials & 75 & 3.1 & 1.15 \\
& Professionals & 109 & 2.7 & .98 \\
A4 & Officials & 73 & 3.0 & 1.21 \\
& Professionals & 111 & 2.4 & .80 \\
A5 & Officials & 74 & 2.8 & 1.21 \\
& Professionals & 111 & 2.5 & .77 \\
A6 & Officials & 75 & 3.0 & 1.15 \\
& Professionals & 112 & 2.6 & .90 \\
A7 & Officials & 73 & 2.7 & .95 \\
& Professionals & 111 & 2.4 & .74 \\
A8 & Officials & 74 & 2.6 & .99 \\
& Professionals & 111 & 2.3 & .71 \\
\hline
\end{tabular}

Sources: Data Analysis 
Table 4. Significance of Differences in Perspective w.r.t.ICAI Readiness towards Challenges of Convergence Process to IFRS

\begin{tabular}{|c|c|c|c|c|c|c|c|c|}
\hline \multirow[t]{3}{*}{ Statements } & \multirow{2}{*}{\multicolumn{3}{|c|}{$\begin{array}{l}\text { Levene Test for } \\
\text { Equality of Variance }\end{array}$}} & \multirow[t]{3}{*}{$t$} & \multirow[t]{3}{*}{ d.f. } & \multirow[t]{3}{*}{ Sig. } & \multirow{3}{*}{$\begin{array}{l}\text { Mean } \\
\text { Difference }\end{array}$} & \multirow{3}{*}{$\begin{array}{l}S E \\
\text { Diff. }\end{array}$} \\
\hline & & & & & & & & \\
\hline & & $F$ & Sig. & & & & & \\
\hline \multirow[t]{4}{*}{ A1 } & Equal Variances & .03 & .87 & -.57 & 182 & .57 & -.08 & .14 \\
\hline & Assumed & & & & & & & \\
\hline & Equal Variances & & & -.57 & 160.2 & .57 & -.08 & .14 \\
\hline & Not Assumed & & & & & & & \\
\hline \multirow[t]{4}{*}{ A2 } & Equal Variances & .31 & .58 & -.59 & 182 & .55 & -.11 & .19 \\
\hline & Assumed & & & & & & & \\
\hline & Equal Variances & & & -.59 & 162.5 & .55 & -.11 & .19 \\
\hline & Not Assumed & & & & & & & \\
\hline \multirow[t]{4}{*}{ A3 } & Equal Variances & 1.6 & .21 & 2.47 & 182 & $.01 *$ & .39 & .16 \\
\hline & Assumed & & & & & & & \\
\hline & Equal Variances & & & 2.4 & 141.2 & .02 & .39 & .16 \\
\hline & Not Assumed & & & & & & & \\
\hline \multirow[t]{4}{*}{ A4 } & Equal Variances & 17.1 & $.00 * *$ & 3.86 & 182 & .00 & .57 & .15 \\
\hline & Assumed & & & & & & & \\
\hline & Equal Variances & & & 3.56 & 113.7 & $.001 * *$ & .57 & .16 \\
\hline & Not Assumed & & & & & & & \\
\hline \multirow[t]{4}{*}{ A5 } & Equal Variances & 25.8 & $.00 * *$ & 2.50 & 183 & .01 & .36 & .15 \\
\hline & Assumed & & & & & & & \\
\hline & Equal Variances & & & 2.3 & 112.4 & $.02 *$ & .36 & .16 \\
\hline & Not Assumed & & & & & & & \\
\hline \multirow[t]{4}{*}{ A6 } & Equal Variances & 1.6 & .20 & 2.55 & 185 & $.01 * *$ & .38 & .15 \\
\hline & Assumed & & & & & & & \\
\hline & Equal Variances & & & 2.43 & 132.2 & .02 & .38 & .16 \\
\hline & Not Assumed & & & & & & & \\
\hline \multirow[t]{4}{*}{ A7 } & Equal Variances & 4.6 & $.03 * *$ & 2.75 & 182 & .01 & .34 & .12 \\
\hline & Assumed & & & & & & & \\
\hline & Equal Variances & & & 2.61 & 127.3 & $.01 *$ & .34 & .13 \\
\hline & Not Assumed & & & & & & & \\
\hline \multirow[t]{4}{*}{ A8 } & Equal Variances & 12.4 & $.001 * *$ & 2.56 & 183 & .01 & .32 & .12 \\
\hline & Assumed & & & & & & & \\
\hline & Equal Variances & & & 2.40 & 121.5 & $.02 *$ & .32 & .13 \\
\hline & Not Assumed & & & & & & & \\
\hline
\end{tabular}

Note

*Statistics Significant @ 5\% level

**Statistics Significant @ 1\% level

Sources: Data Analysis

Through their favourable answers to Statements A1-A8, respondents expressed satisfaction with ICAI attempts towards the execution method.

Respondent's perception on Statement A1; $49 \%$ of respondents is in agreement with a mean of 2.7. Respondent's perception on Statement A2; only $36 \%$ of respondents are in agreement with a mean of 3.12. 
Respondent's perception on Statement A3; $42 \%$ of respondents were satisfied with a mean of 2.9; Female participants are more in agreement than male respondents. Respondent's having experience equal or less than 15 years were found to be more in agreement on the statement if compared with those participants with more than 15 years' of experience as former participants had studied the Ind-AS as part of ICAI course curriculum and were found to be satisfied.

Respondent's perception on Statement A7; $51 \%$ of respondents were satisfied with a mean of 2.51. CA-qualified participants acknowledge the ICAI efforts than non-CA participants. Percentage of females are more in agreement than percentage of males. Moreover, respondent's having experience equal or less than 15 years showed more percentage of agreement with the statement when compared with those participants with more than 15 years' of experience.

Respondent's perception on Statement A4; as publications provide updates on recent developments and with a mean of 2.6; 54\% of respondents agreed with the same. CA qualified participants are more aware than non-CA-educated participants. Respondent's having experience equal or less than 15 years showed more percentage of agreement with the statement when compared with those participants with more than 15 years' of experience. Respondents employed in NCE found to be in agreement more strongly with the statement than those employed in CE. Female respondents found to be more in agreement than male respondents.

Respondent's perception on Statement A5; with a mean of 2.6; 53\% of participants agreed with the statement. CA-qualified participants are more aware than non-CA-qualified participants. There was a greater amount of consciousness among female participants than among male participants. Respondent's having experience equal or less than 15 years are more in agreement with the statement when compared with those participants with more than 15 years' of experience.

Respondent's perception on Statement A6; with the mean of 2.8; $44 \%$ of participants agreed upon that ICAI has given appropriate action to promote the transfer of the integration method. CA-qualified participants are more conscious of the shift than those who are not CA-qualified. The statement was more heavily accepted by female participants than by male participants. In addition, Respondent's having knowledge equal or less than 15 years demonstrated a greater amount of esteem for ICAI than those participants with more than 15 years' of experience.

Respondent's perception on Statement A8; around 57\% of the survey participants believed that recent knowledge of upgrading AS to Ind GAAP in line of US GAAP facilitates India to adopt IFRS. CA-qualified participants are more in agreement than those who are not CA-qualified.

Professionals' and officials showed considerable variations to A3-A8 statements as identified from their means of responses. Based on survey findings, officials getting a greater mean response, demonstrating that ICAI readiness respondents in IFRS convergence method are more comfortable than accounting experts (table-4). ICAI requires to communicate more with professionals to know initiatives taken and advancement in the method of convergence to IFRS.

Table 5. Means of Participants Agreement w.r.t Challenges in Convergence Process to IFRS

\begin{tabular}{llllll}
\hline Statements & Statements Description & Mean & N & Agreement \% \\
\hline B1 & $\begin{array}{l}\text { Various stakeholders faces practical execution } \\
\text { difficulties. }\end{array}$ & 180 & 69.4 \\
B2 & $\begin{array}{l}\text { Medium and tiny units' faces problems w.r.t. technically } \\
\text { sound and skilled staff as a consequence of } \\
\text { harmonization with IFRS. }\end{array}$ & 181 & 59.7 \\
B3 & $\begin{array}{l}\text { The method of transition to IFRS is expensive, } 2.5 \\
\text { complicated and burdensome. }\end{array}$ & 185 & 44.9 \\
B4 & $\begin{array}{l}\text { Costs of coaching, consultancy facilities, information } \\
\text { system adaptation, and computer software modification } \\
\text { are the fields of interest. }\end{array}$ & 182 & 80.1 \\
B5 & $\begin{array}{l}\text { Implementation method faces translation, language and } \\
\text { terminology issues with respect to IFRS. }\end{array}$ & 180 & 67.1 \\
B6 & $\begin{array}{l}\text { Conversion costs to IFRS are an issue of interest. } \\
\text { B }\end{array}$ & 2.1 & 187 & 69.6 \\
\hline
\end{tabular}

Sources: Data Analysis 
Table 6. Significance of Differences in Perspective w.r.t. Challenges in Convergence Process to IFRS

\begin{tabular}{lllll}
\hline Statements & Nature of Respondents & N & Mean & Std. Deviation \\
\hline B1 & Officials & 72 & 2.5 & .93 \\
& Professionals & 108 & 2.1 & 1.07 \\
B2 & Officials & 72 & 2.4 & 1.11 \\
& Professionals & 109 & 2.6 & 1.34 \\
B3 & Officials & 75 & 2.6 & 1.13 \\
& Professionals & 110 & 2.5 & .91 \\
B4 & Officials & 71 & 2.1 & .96 \\
& Professionals & 111 & 2.0 & .87 \\
B5 & Officials & 70 & 2.3 & 1.15 \\
& Professionals & 110 & 2.3 & 1.01 \\
B6 & Officials & 76 & 2.1 & 1.07 \\
& Professionals & 111 & 2.1 & .94 \\
\hline
\end{tabular}

Sources: Data Analysis

Table 7. Levene Test

\begin{tabular}{|c|c|c|c|c|c|c|c|c|}
\hline \multirow[t]{2}{*}{$\begin{array}{l}S . \\
\text { No. }\end{array}$} & \multicolumn{3}{|c|}{ Equality of Variances } & \multirow[t]{2}{*}{$t$} & \multirow[t]{2}{*}{ d.f. } & \multirow[t]{2}{*}{ Sig. } & \multirow[t]{2}{*}{$\begin{array}{l}\text { Mean } \\
\text { Difference }\end{array}$} & \multirow[t]{2}{*}{$\begin{array}{l}\text { SE } \\
\text { Diff. }\end{array}$} \\
\hline & & $\boldsymbol{F}$ & Sig. & & & & & \\
\hline \multirow[t]{3}{*}{ B1 } & Equal Variances & & & & & & & \\
\hline & $\begin{array}{l}\text { Assumed } \\
\text { Equal Variances }\end{array}$ & .15 & .70 & 2.84 & 178 & $.005 * *$ & .44 & .15 \\
\hline & Not Assumed & & & 2.92 & 165.6 & .004 & .44 & .15 \\
\hline \multirow[t]{3}{*}{ B2 } & Equal Variances & & & & & & & \\
\hline & $\begin{array}{l}\text { Assumed } \\
\text { Equal Variances }\end{array}$ & 4.16 & $.04 *$ & -.70 & 179 & .48 & -.13 & .19 \\
\hline & Not Assumed & & & -.78 & 169.9 & .47 & -.13 & .18 \\
\hline \multirow[t]{2}{*}{ B3 } & $\begin{array}{l}\text { Equal Variances } \\
\text { Assumed } \\
\text { Equal Variances }\end{array}$ & 4.92 & $.03 *$ & .37 & 183 & .71 & .05 & .15 \\
\hline & Not Assumed & & & .35 & 135.5 & .72 & .05 & .16 \\
\hline \multirow[t]{2}{*}{ B4 } & $\begin{array}{l}\text { Equal Variances } \\
\text { Assumed } \\
\text { Equal Variances }\end{array}$ & 7.84 & $.01^{* *}$ & 1.09 & 180 & .28 & .15 & .14 \\
\hline & Not Assumed & & & 1.06 & 138.29 & .29 & .15 & .14 \\
\hline \multirow[t]{2}{*}{ B5 } & $\begin{array}{l}\text { Equal Variances } \\
\text { Assumed } \\
\text { Equal Variances }\end{array}$ & 1.23 & .27 & -.02 & 178 & .99 & -.01 & .16 \\
\hline & Not Assumed & & & -.01 & 132.62 & .99 & -.01 & .17 \\
\hline \multirow[t]{2}{*}{ B6 } & $\begin{array}{l}\text { Equal Variances } \\
\text { Assumed } \\
\text { Equal Variances }\end{array}$ & 1.67 & .20 & .22 & 185 & .83 & .03 & .15 \\
\hline & Not Assumed & & & .21 & 147.07 & .83 & .03 & .15 \\
\hline
\end{tabular}

\section{Note}

*Statistics Significant @ 5\% level

**Statistics Significant @ 1\% level

Sources: Data Analysis 
Table 8. Significance of Differences in Perspective w.r.t. Demographic Characteristics

\begin{tabular}{|c|c|c|c|c|c|c|c|c|c|c|c|c|}
\hline \multirow[b]{2}{*}{ 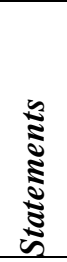 } & \multicolumn{3}{|c|}{ Gender } & \multicolumn{3}{|c|}{ Qualification } & \multicolumn{3}{|c|}{ Experience } & \multicolumn{3}{|c|}{$\begin{array}{l}\text { Employment } \\
\text { Ownership }\end{array}$} \\
\hline & $M$ & $\boldsymbol{F}$ & Sig. & $\boldsymbol{C A}$ & NonCA & Sig. & $\begin{array}{l}\leq 15 \\
\text { Years }\end{array}$ & $\begin{array}{l}>15 \\
\text { Years }\end{array}$ & Sig. & $N C E$ & $C E$ & Sig. \\
\hline A1 & 2.7 & 2.5 & 0.12 & 2.7 & 2.7 & 0.89 & 2.7 & 2.7 & 0.79 & 2.6 & 2.7 & 0.74 \\
\hline $\mathrm{A} 2$ & 3.2 & 2.8 & 0.10 & 3.2 & 3.0 & 0.45 & 3.0 & 3.2 & 0.32 & 3.2 & 3.0 & 0.26 \\
\hline A3 & 3.0 & 2.4 & $0.001 * *$ & 2.8 & 3.1 & $0.04 *$ & 2.7 & 3.1 & $0.02 *$ & 3.0 & 2.8 & 0.21 \\
\hline A4 & 2.7 & 2.3 & $0.03 *$ & 2.4 & 3.0 & $0 * *$ & 2.4 & 2.8 & $0.005^{* *}$ & 2.8 & 2.4 & $0.02 *$ \\
\hline A5 & 2.7 & 2.3 & $0.03 *$ & 2.5 & 2.9 & $0.01 *$ & 2.4 & 2.8 & $0.005^{* *}$ & 2.7 & 2.5 & 0.33 \\
\hline A6 & 2.9 & 2.5 & $0.04 *$ & 2.7 & 3.0 & $0.02 *$ & 2.6 & 3.0 & $0.01 * *$ & 2.8 & 2.8 & 0.67 \\
\hline A7 & 2.6 & 2.2 & $0.02 *$ & 2.4 & 2.7 & $0.01 * *$ & 2.4 & 2.6 & $0.04 *$ & 2.6 & 2.4 & 0.30 \\
\hline $\mathrm{A} 8$ & 2.5 & 2.1 & $0.03 *$ & 2.3 & 2.6 & $0.02 *$ & 2.3 & 2.6 & $0.02 *$ & 2.5 & 2.3 & 0.19 \\
\hline B1 & 2.3 & 1.8 & $0.004 * *$ & 2.1 & 2.5 & $0.01 *$ & 2.1 & 2.4 & 0.08 & 2.3 & 2.1 & 0.08 \\
\hline B2 & 2.5 & 2.6 & 0.6 & 2.5 & 2.5 & 0.82 & 2.5 & 2.5 & 0.93 & 2.7 & 2.3 & $0.02 *$ \\
\hline B3 & 2.6 & 2.3 & 0.1 & 2.5 & 2.7 & 0.14 & 2.5 & 2.5 & 0.86 & 2.7 & 2.3 & $0.01 *$ \\
\hline B4 & 2.1 & 1.9 & 0.33 & 2.0 & 2.1 & 0.31 & 2.0 & 2.1 & 0.56 & 2.2 & 1.9 & $0.02 *$ \\
\hline B5 & 2.4 & 2.1 & 0.09 & 2.3 & 2.4 & 0.7 & 2.4 & 2.3 & 0.78 & 2.4 & 2.3 & 0.31 \\
\hline B6 & 2.2 & 1.8 & $0.02 *$ & 2.1 & 2.2 & 0.72 & 2.2 & 2.0 & 0.33 & 2.2 & 2.0 & 0.12 \\
\hline
\end{tabular}

\section{Note}

*Statistics Significant @ 5\% level

**Statistics Significant @ 1\% level

$\mathrm{M}=$ Male, $\mathrm{F}=$ Female

Sources: Data Analysis

Statements B1-B6 as shown in the table-6 will address research question 2 and reveals the respondents' perspectives w.r.t. challenges faced during Ind-AS implementation.

Respondents' perception on Statement B1; with a mean response of 2.2; 70\% of the respondents conveyed concern on the same. Officials expresses a greater level of concern over Professionals. CA-qualified participants are more aware about challenges due to their frequent involvement in ICAI organized or sponsored seminars, conferences, and development programs on IFRS when compared with non-CA-qualified participants. Female participants are more aware about implementation challenges.

Respondents' perception on Statement B2; with a mean response of 2.5, around $60 \%$ of the survey respondents were found anxious on statement. Respondents employed in NCE found to be in agreement more strongly with the statement than those employed in CE.

Respondents' perception on Statement B3; with a mean response of 2.5 , approximately $45 \%$ of the survey respondents expressed concern. Respondents employed in NCE found to be in agreement more strongly with the statement than those employed in CE.

Respondents' perception on Statement B4; with a mean response of 2.0, about $80 \%$ of participants showed concern with the discussed statement. Respondents employed in NCE found to be in agreement more strongly with the statement than those employed in CE.

Respondents' perception on Statement B5; with a mean response of $2.3,67 \%$ of the respondents acknowledged in favour of the statement; and suggested ICAI to make the process of convergence easy.

Respondents' perception on Statement B5; with a mean response of 2.1, approximately 69\% of respondents showed concern w.r.t. cost to be incurred on the process; female participants are more concerned with the statement. 
So, it is inferred from the analysis that no significant difference exists within viewpoints of both officials and professionals on statements B2-B6 (table-7 and table-8). CA-qualified participants found to be more aware and concern about execution problems. This may be the result of various programs launched by ICAI. This also highlights the need for organising many more programs on IFRS even for non-CA-qualified participants.

\section{Discussion, Findings, Implications and Conclusions}

A thorough analysis of the literature accessible on the topic gives extensive proof of studies on developed economies, but few on emerging nations. Moreover, there is absence of studies in India. Due to the minimal previous studies on the execution problems experienced by the respondents, the scope of this study was recognized more in the framework of emerging countries, especially in the early-adoption stage.

It is identified that professionals and officials agreed on the importance and usefulness of globally harmonizing AS but do not find it easy to adapt IND-AS to IFRS and have many concerns over it. Moreover, IASB is not properly emphasising in smoothening the process of implementation other than just organizing training sessions. Young and skilled professionals appreciated more of the IFRS implementation than elderly and less skilled. Female participants are more receptive than men. Indian software companies were already using US GAAP norms for more than a century.

The literature accessible on India now-a-days is a result of outcomes drawn from the available studies conducted on other nations and are then contextualised in India context differently by different researchers based on their expertise, knowledge and experience (Firoz, C. M., Ansari, A. A., and Akhtar, K., 2011) (Jain, P., 2011) (Rathod, T. G., 2006) (Ray, S., 2012). Further, another researcher (Rudra, Titas, and Dipanjan Bhattacharjee, Ca., 2011) used statistical methods and available secondary information to comprehend the impact of IFRS application on reports of companies (Ray, S., 2012) (Rudra, Titas, and Dipanjan Bhattacharjee, Ca., 2011) or on banks (Firoz, C. M., Ansari, A. A., and Akhtar, K., 2011). Implementation, advantages, and grounds to adopt IFRS differs from nation to nation based on accounting and legislative frameworks, background and other factors (Bhattacharyya, K., 2012). Therefore, to comprehend the impact of local variables, a country-specific survey was needed. In perspective of the increasing impact of developing markets in the world economy, the need for this study becomes more evident. These countries face an intuitive legislative and financial framework that is comparatively less advanced; hence, this became the main motive of this research to conduct an exploratory study on India considering its growth rate and also to contribute significantly in available literature on IFRS.

In the coming years, IFRS is anticipated to adjust to the specific Indian accounting systems structure. It involves inserting fresh techniques, regulations, conditions and tools of assessment into Indian businesses. Live research and surveys need to be properly collected, analysed and assimilated into present studies to guarantee a gentle shift down the track.

This article focuses exclusively on two classifications of officials and professionals. Participants of both group agreed on the importance and usefulness of globally harmonizing AS. At the same moment, both group are expecting a substantial amount of difficulties during the transformation phase. Young and skilled professionals appreciated more of the IFRS implementation than elderly and less skilled. Female participants are more receptive than men.

Indian software companies were already using US GAAP norms for more than a century, a section of the accounting society has a wider global view, but this is not uniformly distributed throughout. There have been prevalent problems with regard to fields of interest such as costs analysis, infrastructure, and staffing. Observation of practice and consciousness difficulties reflect those of past empirical research that outlined multiple problems of execution in terms of awareness, training, price, analysis, IT infrastructure and staffing (Ballas, A., Skoutela, D., and Tzovas, C., 2010) (Ion Ionas, cu, Mihaela Ionas, cu, Lavinia Olimid, and Daniela Artemisa Calu., 2007) (Jermakowicz, Eva, \& Gornik-Tomaszewski, Sylwia., 2006) (Jones, Stewart, and D., Higgins, Alison., 2006) (A., Zeff, Stephen., 2007). Research on Greece, Australia, and the EU, have shown the same issues (Ballas, A., Skoutela, D., and Tzovas, C., 2010) (Jones, Stewart, and D., Higgins, Alison., 2006). After checking the application of IFRS globally, the significance of training for regulators has also been noted (A., Zeff, Stephen., 2007). Special attempts on training the prospective workforce is desired from accounting bodies. This also needs IASB assistance to achieve worldwide IFRS implementation in a smooth manner.

There has been a blended reaction to ICAI training programs, but the reaction has not been dismissive. This study is reflective of a substantial study domain involving problems before IFRS application. As it does not address the problem arising during complete process; its scope can be improved by including experts from real estate, BFI, infrastructure, technology, pharmaceutical or from commerce ministry. In analysing these industries, the findings 
could be used as a benchmark. Furthermore, problems relating to the implementation of IFRS regulations could be understood more impressively if examined in respect to taxation, debt assessment, or certain other problems that directly or indirectly affects IFRS. This preparation is important as many professionals and officials work for overseas companies during their jobs with BPO. This is just a start, though. Before it becomes completely commonplace, IFRS must conduct a lengthy voyage in the Indian subcontinental room. Until then, a concentrated survey may be required in all prospective fields to address them and establish a sustainable roadmap for universal accounting. As a schedule for execution started on $1^{\text {st }}$ April 2016 has only lately been suggested, further ICAI attempts can be conducted in the future on training and awareness programs. The next stage for ICAI must be on organising training programs including the topic in its curriculum and beyond its employees. In the former, the ICAI was discovered to be skilled enough to correspond with the US GAAP when upgrading the AS to Ind GAAP.

\section{Limitations}

Following study has a limitation as it is undertaken only in India that recently announced to upgrade it's AS in conference with IFRS and its application process. The sample of study is restricted to officials and professionals, and may not be a representative sample. Usual constraints such as the questionnaire design and the participants' biases, may affect the study outcomes. While the survey results show reactions from only one nation and from a particular group of chosen participants, the research findings are intended to direct professionals and officials, regulatory authorities and bodies in regards to problems experienced by countries that have lately launched the IFRS implementation or convergence method. For instance, nations such as India and China initially showed hesitation due to institutional and professionalism barriers before they accepted IFRS convergence. The results of this research indicate that, to updating / making IFRS, the IASB should now concentrate on implementing IFRS in order to minimize the problems experienced by respondents in execution other than updating IFRS.

\section{Suggestions and Contributions}

Involvement of corporate houses, local authorities, boards, national agencies, professionals and officials are required for success of IFRS adoption. The paper provides an insight on opinion of professionals and professionals to decision makers. The Author is preparing to submit a report to IASB to facilitate them in bringing effectiveness for the same purpose.

Based on the literature review, corporate governance is identified as an important area as the scope of further study in order to bring the effectiveness in implementation phase of IFRS within Indian companies, and to identify different factors that increases risk of failure.

Further, it is important to study the role of monitoring institutions, regulators, and government in encouraging professionals and officials to smoothen the implementation phase in India. Nevertheless, effects after implementation need to be studied further.

The author is preparing to submit a report to IASB and Indian Government to facilitate them and to speed up the process in bringing effectiveness for the same purpose.

\section{References}

A., Zeff, Stephen. (2007). Some Obstacles to Global Financial Reporting Comparability and Convergence at a High Level of Quality. The British Accounting Review, 39, 290-302. https://doi.org/10.1016/j.bar.2007.08.001

Adhana, D. K. (2015). Convergence with International Financial Reporting Standards (IFRS) in India. Available at http://papers.ssrn.com/sol3/papers.cfm?abstract_id2687004 (accessed on $3^{\text {rd }}$ August 2019). https://doi.org/10.2139/ssrn.2687004

Ahmed, A. S., Neel, M. \& Wang, D. (2013). Does Mandatory Adoption of IFRS Improve Accounting Quality?

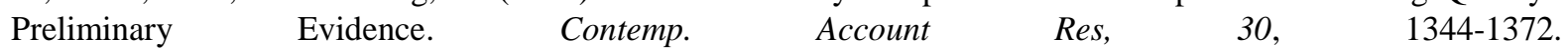
https://doi.org/10.1111/j.1911-3846.2012.01193.x

Ahmed, Kamran \& Ali, Muhammad. (2015). Has the harmonisation of accounting practices improved? Evidence from South Asia. International Journal of Accounting and Information Management, 23, https://doi.org/10.1108/IJAIM-12-2014-0082

Ball, Ray. (2006). International Financial Reporting Standards (IFRS): Pros and Cons for Investors. Regulation of Financial Institutions eJournal, 36. https://doi.org/10.1080/00014788.2006.9730040

Ballas, A., Skoutela, D. \& Tzovas, C. (2010). The relevance of IFRS to an emerging market: evidence from Greece. Managerial Finance, 36(11), 931-948. https://doi.org/10.1108/03074351011081259 
Barth, M. E., Landsman, W. R., Lang, M. \& Williams, C. (2012). Are IFRS-based and US GAAP based accounting amounts comparable? Journal of Accounting and Economics, 54(1), 68-93. https://doi.org/10.1016/j.jacceco.2012.03.001

Bhattacharyya, K. (2012). India's adoption of IFRS: Advantages and Challenges. Journal of Commerce \& Management Thought, 3(3), 379-380. Available at http://www.indianjournals.com/ijor.aspx ?target=ijor:jcmt \&volume $=3 \&$ issue $=3 \&$ article $=$ abs 007 (accessed on $5^{\text {th }}$ August 2019).

Braun, G. P., Haynes, C. M., Lewis, T. D. \& Taylor, M. H. (2015). Principles-Based Vs. Rules-Based Accounting Standards: The Effects of Auditee Proposed Accounting Treatment and Regulatory Enforcement on Auditor Judgments and Confidence. Research in Accounting Regulation, 2015 April, 27(1), 45-50. https://doi.org/10.1016/j.racreg.2015.03.005

Brüggemann, U., Hitz, J.-M. \& Sellhorn, T. (2013). Intended and unintended consequences of mandatory IFRS adoption: A review of extant evidence and suggestions for future research. European Accounting Review, 22(1), 1-37. https://doi.org/10.1080/09638180.2012.718487

Buckingham, A. \& Saunders, P. (2004). The Survey Methods Workbook: from Design to Analysis. Cambridge, U.K.; Malden, Ma.: Polity, c2004, xiii, 309 p.: ill.; 25 cm. ISBN.: 0745622445,9780745622446

Cascino, Stefano \& Gassen, Joachim. (2015). What Drives the Comparability Effect of Mandatory IFRS Adoption? Review of Accounting Studies, 20, 242-282. https://doi.org/10.1007/s11142-014-9296-5

Claire, Marston \& Paul, Robson. (1997). Financial Reporting in India: Changes in Disclosure over the Period 1982 to 1990. Asia-Pacific Journal of Accounting, 4(1), 109-140. https://doi.org/10.1080/10293574.1997.10510513

Delvaille, Pascale, \& Ebbers, Gabi \& Saccon, Chiara. (2005). International Financial Reporting Convergence: Evidence from Three Continental European Countries. Accounting in Europe, 2, 137-164. https://doi.org/10.1080/09638180500379103

Dhankar, R. S. \& Gupta, A. (2014). Transition to International Financial Reporting Standards (IFRS) or IND as in India. Global J Finance Manage, 6(7), 609-614

Dhankar, Raj, Chaklader, Barnali \& Gupta, Amit. (2015). Implementing IFRS from the perspective of public sector banks in India. In International Conference on Accounting Studies (ICAS) 2015, 17-20 August 2015, Johor Bahru, Johor, Malaysia.

E. Barbu \& C. Richard Baker. 2009. Institutions Involved in International Convergence of Accounting Standards: A Neo-Institutional and Historical Analysis. Post-Print halshs-00518989, HAL.

E. Perumpral, Shalini, Evans, Mark, Agarwal, Sanjay \& Amenkhienan, Felix. (2009). The evolution of Indian accounting standards: Its history and current status with regard to International Financial Reporting Standards. Advances in Accounting, 25, 106-111. https://doi.org/10.1016/j.adiac.2009.02.003

Eva, K. Jermakowicz. (2004). Effects of Adoption of International Financial Reporting Standards in Belgium: The Evidence from BEL-20 Companies. Accounting in Europe, 1(1), 51-70, https://doi.org/10.1080/0963818042000270811

Firoz, C. M., Ansari, A. A. \& Akhtar, K. (2011). IFRS-impact on Indian banking industry. International Journal of Business \& Management, 6(3), 277. https://doi.org/10.5539/ijbm.v6n3p277

Foo, Y. F. (2008). A cross-cultural study of accounting concepts applied in international financial reporting standards (Doctoral dissertation, Victoria University).

Fox A., Hannah, G., Helliar, C. \& Veneziani, M. (2013). The costs and benefits of IFRS Implementation in the UK and Italy. Journal of Applied Accounting Research, 14(1), 86-101. https://doi.org/10.1108/09675421311282568

Guerreiro, Marta Silva, Rodrigues, Lúcia Lima \& Craig, Russell. (2012). Voluntary adoption of International Financial Reporting Standards by large unlisted companies in Portugal - Institutional logics and strategic responses. Accounting, Organizations and Society, Elsevier, 37(7), 482-499. https://doi.org/10.1016/j.aos.2012.05.003 
H., Lang, Mark \& G., Maffett, Mark, \& L., Owens, Edward. (2010). Earnings Comovement and Accounting Comparability: The Effects of Mandatory IFRS Adoption. Working Paper, SSRN eLibrary. https://doi.org/10.2139/ssrn.1676937

Heidhues, E. \& Patel, C. (2008). Convergence of accounting standards in Germany: biases and challenges. In C. Han (Ed.), Proceedings of the 10th International Conference on Accounting \& Business 2008 China: East China University of Science \& Technology.

Heidhues, Eva \& Patel, Chris. (2011). Chapter 3 Adoption of IFRS in Germany: A Neo-Institutional Analysis. Studies in Managerial and Financial Accounting, 23, 43-74. https://doi.org/10.1108/S1479-3512(2012)0000023008

I. Ocheni, S. (2015). Perceived Challenges of International Financial Reporting Standards (IFRS) Adoption in Nigeria. Indian Journal of Commerce and Management Studies, 07-11. Available at http://scholarshub.net/index.php/ijcms/article/view/563 (accessed on $5^{\text {th }}$ August 2019).

ICAI. (2014). The Institute of Chartered Accountants of India, President's Message - April 2014 - (31-03-2014). Available at https://www.icai.org/new_post.html?post_id=10591 (accessed on $5^{\text {th }}$ August 2019).

IFRS Convergence in India: Some Progress on Implementation. Available at https://economictimes.indiatimes.com/policy/ifrs-convergence-in-india-some-progress-on-implementation/articl eshow/7631924.cms?from=mdr (accessed on $5^{\text {th }}$ August 2019).

IFRS in India. Keshav Kumar \& Virender Atwal. 2014.2,s.1.: IRJMSH, 2014, International Research Journal of Management Sociology \& Humanities, 5, Available at www.IRJMSH.com

IFRS. (2018). IFRS Foundation Constitution - December 2018. Available at https://www.ifrs.org/-/media/feature/about-us/legal-and-governance/constitution-docs/ifrs-foundation-constituti on-2018.pdf?la=en (accessed on $5^{\text {th }}$ August 2019).

IFRS. Who Use IFRS Standards. Available at https://www.ifrs.org/use-around-the-world/use-of-ifrs-standards-by-jurisdiction/ (accessed on $5^{\text {th }}$ August 2019).

Innes, John. (1990). External Management Auditing of Companies: A Survey of Bankers. Accounting, Auditing \& Accountability Journal. 3. https://doi.org/10.1108/09513579010136488

Ion Ionas scu, Mihaela Ionas, cu, Lavinia Olimid \& Daniela Artemisa Calu. (2007). An Empirical Evaluation of the Costs of Harmonizing Romanian Accounting with International Regulations (EU Directives and IAS/IFRS). Accounting in Europe, 4(2), 169-206, https://doi.org/10.1080/17449480701727965

Irvine, Helen. (2008). The Global Institutionalization of Financial Reporting: The Case of the United Arab Emirates. Accounting Forum, 32, 125-142. Available at 10.1016/j.accfor.2007.12.003. https://doi.org/10.1016/j.accfor.2007.12.003

Jain, P. (2011). IFRS implementation in India: Opportunities and Challenges. World Journal of Social Sciences, 1(1), 125-136.

Jeanjean, Thomas \& Stolowy, Hervé. (2008). Do Accounting Standards Matter? An Exploratory Analysis of Earnings Management Before and After IFRS Adoption. Journal of Accounting and Public Policy, 27, 480-494. https://doi.org/10.1016/j.jaccpubpol.2008.09.008

Jermakowicz, Eva, \& Gornik-Tomaszewski, Sylwia. (2006). Implementing IFRS from the perspective of EU publicly traded companies. Journal of International Accounting, Auditing and Taxation, 15, 170-196. https://doi.org/10.1016/j.intaccaudtax.2006.08.003

Jones, Stewart \& D., Higgins, Alison. (2006). Australia's Switch to International Financial Reporting Standards: A Perspective from Account Preparers. Accounting and Finance, 46, 629-652, https://doi.org/10.1111/j.1467-629X.2006.00186.x

Jones, Stewart \& Finley, Aimee. (2011). Have IFRS Made a Difference to Intra-Country Financial Reporting Diversity? The British Accounting Review, 43, 22-38. https://doi.org/10.1016/j.bar.2010.10.004

Joshi, M., Yapa, P. \& Kraal, D. (2016). IFRS adoption in ASEAN countries: Perceptions of professional accountants from Singapore, Malaysia and Indonesia. International Journal of Managerial Finance, 12(2), 211-240. https://doi.org/10.1108/IJMF-04-2014-0040 
Joshi, PL, Bremser, WG \& Al-Ajmi, J. (2008). Perceptions of accounting professionals in the adoption and implementation of a single set of global accounting standards: Evidence from Bahrain. Advances in Accounting, 24(1), 41-48. https://doi.org/10.1016/j.adiac.2008.05.007

Judge, W., Li, S. \& Pinsker, R. (2010). National Adoption of International Accounting Standards: An Institutional Perspective. Corporate Governance: An International Review, 18, 161-174. https://doi.org/10.1111/j.1467-8683.2010.00798.x

Kanakriyah, R. (2013). The effect of Asset Impairment (IAS 36) in Improving the Quality of Accounting Information According to Users' Perspective: Evidence from Jordan. Doctoral Thesis, Durham University, UK.

Mackintosh, I. (November 2014). The maturing of IFRS. Available at https://www.ifrs.org/-/media/feature/news/speeches/2014/ian-mackintosh-november-2014.pdf (accessed on $5^{\text {th }}$ August 2019).

Mahzan, Nurmazilah. (2013). The Responses of Malaysian Public Listed Companies to the IFRS Convergence. Asian Journal of Business and Accounting, 6(1), 95. 6. 95.

Martin, Hoogendoorn. (2006). International Accounting Regulation and IFRS Implementation in Europe and Beyond - Experiences with First-time Adoption in Europe. Accounting in Europe, 3(1), 23-26. https://doi.org/10.1080/09638180600920087

MCA. (2015). Road map for companies other than banking companies, insurance companies and non-banking finance companies (NBFC's) for implementation of Indian Accounting Standards (Ind AS) converged with the International Financial Reporting Standards (IFRS). Available at http://www.mca.gov.in/Ministry/pdf/PressRelease_06012015.pdf (accessed on $5^{\text {th }}$ August 2019).

MCA. (2016). Roadmap drawn-up for implementation of Indian Accounting Standards (Ind AS) converged with International Financial Reporting Standards (IFRS) for Scheduled Commercial Banks (Excluding Rrbs), Insurers/Insurance Companies and Non-Banking Financial Companies (NBFC's). Available at http://pib.nic.in/newsite/PrintRelease.aspx?relid=134578 (accessed on $5^{\text {th }}$ August 2019).

Mir, Monir \& Shiraz Rahaman, Abu. (2005). The adoption of International Accounting Standards in Bangladesh: An exploration of rationale and process. Accounting, Auditing \& Accountability Journal, 18, 816-841. https://doi.org/10.1108/09513570510627720

Mishra, S. K. \& Aggarwal, V. (2014). Strategies, Benefits and Challeges of Adoption of IFRS in India. International Journal of Accounting and Financial Management Research (IJAFMR), 4(6), 17-26. Available at https://www.academia.edu/10469776/STRATEGIES_BENEFITS_AND_CHALLEGES_OF_ADOPTION_OF _IFRS_IN_INDIA (accessed on $5^{\text {th }}$ August 2019).

Morris, Richard, Gray, Sidney, Pickering, Joanne \& Aisbitt, Sally. (2014). Preparers' Perceptions of the Costs and Benefits of IFRS: Evidence from Australia's Implementation Experience. Accounting Horizons, 28, 143-173. https://doi.org/10.2308/acch-50609

Naoum, Vasilios-Christos, Sykianakis, Nicos \& Tzovas, Christos. (2012). The perceptions of managers of Greek firms regarding the Costs and Benefits ensuing from the adoption of International Financial Reporting Standards in Greece. International Journal of Economic Sciences and Applied Research (IJESAR), 4, 59-74,

Naoum, Vasilios-Christos, Sykianakis, Nicos \& Tzovas, Christos. (2012). The perceptions of managers of Greek firms regarding the Costs and Benefits ensuing from the adoption of International Financial Reporting Standards in Greece. International Journal of Economic Sciences and Applied Research (IJESAR), 4, 59-74.

Pacter, P. (2014). Global Accounting Standards-From Vision to Reality. The CPA Journal, 84(1). Available at https://www.questia.com/magazine/1P3-3234807141/global-accounting-standards-from-vision-to-reality (accessed on $5^{\text {th }}$ August 2019).

Pawsey, N. L. (2008). Australian Preparer Perceptions towards the Quality and Complexity of IFRS. PhD Thesis, La Trobe University. Available at http://apira2010.econ.usyd.edu.au/conference_proceedings/APIRA-2010-199-Pawsey-Australian-preparer-perc eptions-of-IFRS.pdf (accessed on $5^{\text {th }}$ August 2019).

Phan, D., Joshi, M. \& Mascitelli, B. (2016) International Financial Reporting Standards (IFRS) Adoption in Vietnam: From Isolation to Isomorphism' in E Uchenna et al (ed.) Economics and Political Implications of International 
Financial Reporting Standards, IGI Global, Hershey, United States, 266-281. https://doi.org/10.4018/978-1-4666-9876-5.ch013

Rathod, T. G. (2006). IFRSs: Emerging Opportunities and Challenges for India. The Chartered Accountant, 54 (7), 988-992. Available at https://www.scribd.com/document/71783014/IFRS-Opportunities-Challenges-for-India (accessed on $5^{\text {th }}$ August 2019).

Ray, S. (2012). Applicability of international financial reporting standards in India: Some key issues and challenges. Journal of Expert Systems, 1, 1-15.

RBI (14 $4^{\text {th }}$ February 2011). Introduction of IFRS- Issues and Challenges. (Speech delivered by Dr. K C Chakrabarty, Deputy Governor, Reserve Bank of India at the inauguration of a national level seminar on IFRS- at Prahladrai Dalmia Lions College of Commerce \& Economics, Mumbai on February 11, 2011). Available at https://www.rbi.org.in/Scripts/BS_SpeechesView.aspx?Id=549 (accessed on $5^{\text {th }}$ August 2019).

Rezaee, Zabihollah, Smith, Murphy \& Z., Szendi, Joseph. (2010). Convergence in Accounting Standards: Insights from Academicians and Practitioners. Advances in Accounting, 1. https://doi.org/10.1016/j.adiac.2010.01.001

Riahi-Belkaoui, A. (1994). Accounting in the Developing Countries. Westport, Conn.: Quorum Books. ISBN-13: 978-0899308210, ISBN-10: 089930821X

Ritsumeikan, L. (2011). An Institutional Perspective on International Financial Reporting Standards Adoption in Developing Countries. Academy of Accounting and Financial Studies Journal, 15, 61-72,

Rudra, Titas \& Dipanjan Bhattacharjee, Ca. (2011). Does IFRs Influence Earnings Management? Evidence from India. Journal of Management Research, 4. https://doi.org/10.5296/jmr.v4i1.849

Schleicher, Thomas, Tahoun, Ahmed \& Walker, Martin. (2010). IFRS Adoption in Europe and Investment-Cash Flow Sensitivity: Outsider versus Insider Economies. The International Journal of Accounting, 45, 143-168. https://doi.org/10.1016/j.intacc.2010.04.007

Sharma, S., Joshi, M. \& Yapa, P. (2016). IFRS Convergence in India: an exploration of rationale and Institutional Pressures. In 8th Asia-Pacific Interdisciplinary Research in Accounting Conference (APIRA-2016), RMIT University, Melbourne, Australia 13 - 15 July 2016. Available at https://www.xcdsystem.com/APIRA2016/program/index.cfm?pgid=650\&day=14\&sid=20834 $\left(\right.$ accessed on $5^{\text {th }}$ August 2019).

Shil, Nikhil, Das, Bhagaban \& Pramanik, Alok. (2009). Harmonization of Accounting Standards through Internationalization. International Business Research, 2. https://doi.org/10.5539/ibr.v2n2p194

Thorne, Linda, Mahoney, Lois \& Manetti, Giacomo. (2014). Motivations for issuing standalone CSR reports: A survey of Canadian firms. Accounting, 27. https://doi.org/10.1108/AAAJ-07-2013-1393

Upton, Wayne. (16 ${ }^{\text {th }}$ April 2010) Adopt, adapt, converge? Available at https://www.scribd.com/document/155503522/Adopt-adapt-converge (accessed on $5^{\text {th }}$ August 2019).

Weaver, Lisa \& Woods, Margaret. (2015). The Challenges Faced by Reporting Entities on their Transition to International Financial Reporting Standards: A Qualitative Study. Accounting in Europe, 12, 1-25. https://doi.org/10.1080/17449480.2015.1103376

Wild, S. \& Van Staden, C. (2013). Integrated Reporting: Initial analysis of early reporters - An Institutional Theory Approach. Available at: www.apira2013.org/proceedings/pdfs/K236.pdf (accessed $5^{\text {th }}$ August 2019)

Yip, Rita \& Young, Danqing. (2012). Does Mandatory IFRS Adoption Improve Information Comparability? The Accounting Review, 87. https://doi.org/10.2308/accr-50192 


\section{Appendix}

Responses w.r.t. ICAI Readiness towards Challenges of Convergence Process to IFRS

\begin{tabular}{|c|c|c|c|c|c|c|c|}
\hline Statements & Responses & $S A$ & $A$ & $N$ & $D$ & $S D$ & Total \\
\hline \multirow{2}{*}{ A1 } & Frequency & 11 & 80 & 57 & 30 & 6 & 184 \\
\hline & Percent & 6 & 43.5 & 31 & 16.3 & 3.3 & 100 \\
\hline \multirow[t]{2}{*}{$\mathrm{A} 2$} & Frequency & 19 & 48 & 44 & 38 & 35 & 184 \\
\hline & Percent & 10.3 & 26.1 & 23.9 & 20.7 & 19 & 100 \\
\hline \multirow[t]{2}{*}{$\mathrm{A} 3$} & Frequency & 11 & 66 & 52 & 40 & 15 & 184 \\
\hline & Percent & 6 & 35.9 & 28.3 & 21.7 & 8.2 & 100 \\
\hline \multirow[t]{2}{*}{$\mathrm{A} 4$} & Frequency & 16 & 84 & 42 & 34 & 8 & 184 \\
\hline & Percent & 8.7 & 45.7 & 22.8 & 18.5 & 4.3 & 100 \\
\hline \multirow[t]{2}{*}{ A5 } & Frequency & 16 & 82 & 47 & 34 & 6 & 185 \\
\hline & Percent & 8.6 & 44.3 & 25.4 & 18.4 & 3.2 & 100 \\
\hline \multirow[t]{2}{*}{ A6 } & Frequency & 14 & 69 & 54 & 41 & 9 & 187 \\
\hline & Percent & 7.5 & 36.9 & 28.9 & 21.9 & 4.8 & 100 \\
\hline \multirow[t]{2}{*}{ A7 } & Frequency & 19 & 75 & 69 & 20 & 1 & 184 \\
\hline & Percent & 10.3 & 40.8 & 37.5 & 10.9 & 0.5 & 100 \\
\hline \multirow[t]{2}{*}{ A8 } & Frequency & 22 & 83 & 63 & 15 & 2 & 185 \\
\hline & Percent & 11.9 & 44.9 & 34.1 & 8.1 & 1.1 & 100 \\
\hline \multirow[t]{2}{*}{ B1 } & Frequency & 43 & 82 & 37 & 8 & 10 & 180 \\
\hline & Percent & 23.9 & 45.6 & 20.6 & 4.4 & 5.6 & 100 \\
\hline \multirow[t]{2}{*}{ B2 } & Frequency & 37 & 71 & 37 & 13 & 23 & 181 \\
\hline & Percent & 20.4 & 39.2 & 20.4 & 7.2 & 12.7 & 100 \\
\hline \multirow[t]{2}{*}{ B3 } & Frequency & 33 & 50 & 76 & 21 & 5 & 185 \\
\hline & Percent & 17.8 & 27 & 41.1 & 11.4 & 2.7 & 100 \\
\hline \multirow[t]{2}{*}{ B4 } & Frequency & 46 & 100 & 22 & 9 & 5 & 182 \\
\hline & Percent & 25.3 & 54.9 & 12.1 & 4.9 & 2.7 & 100 \\
\hline \multirow[t]{2}{*}{ B5 } & Frequency & 35 & 86 & 29 & 22 & 8 & 180 \\
\hline & Percent & 19.4 & 47.8 & 16.1 & 12.2 & 4.4 & 100 \\
\hline \multirow[t]{2}{*}{ B6 } & Frequency & 57 & 73 & 41 & 11 & 5 & 187 \\
\hline & Percent & 30.5 & 39 & 21.9 & 5.9 & 2.7 & 100 \\
\hline
\end{tabular}

Note:

Strongly Agree (SA)

Agreement (A)

Neutral (N)

Disagree (D)

Strongly Disagree (SD)

Sources: Data Analysis 